\title{
Characteristics of Korean ODA Allocation by Sector and Type
}

- Focusing on Comparison with Other DAC Donors -

Jiyoon Kim (KOICA ODA Research Team)

Contents
Introduction
1. Overview of Korean ODA
2. Characteristics of Korean ODA in sector
allocation
3. Features of type allocation of Korean ODA
4. Implication
Conclusion

\section{Abstract}

Korea has been receiving growing attention from the international society since its development has been recognized as the most successful case in history, and it has been expected to deliver its development experiences to developing countries through development cooperation. However, while there are many studies on Korea's development experience, there are not many studies on the features of Korean official development assistance (ODA) and how to reflect Korea's experiences in its aid programs. Thus, Korea's development cooperation system should be studied to identify effective ways to deliver Korea's development know-how to developing countries. 
As the first step to study Korean ODA and its relationship with Korea's development experience, this paper will focus on the special characteristics of Korean ODA's allocation by sector and type which differs from other OECD's Development Assistance Committee (DAC) donors.

Furthermore, should we consider the special features of Korea's aid programs as an immature quality that should be improved in the future, or should it be considered as an alternative that can complement the weakness of other donors' aid? This paper will attempt to answer these questions by analyzing the sector and type allocation of Korean ODA in comparison to other DAC donors.

Keywords: Korean ODA (Official Development Assistance), Korea's development experience

\section{Introduction}

In recent years, Korea's development experience of transforming from one of the world's poorest countries to a donor has drawn much attention from the international development society. It is also emphasized that the Korean development experience needs to be efficiently shared with developing countries in order to contribute to their development. As the Korean development experience is gaining spotlight, an increasing number of voices, both internally and externally, argue that Korea needs to play a role as an intermediary and become a leader in the development paradigm and discussions by utilizing its own unique development experience. However, studies are lacking on how Korea needs to carry out this intermediary role between developed and developing countries and on the meaning and implications of Korea's development experience in international development discussions and paradigms.

In addition, although Korea's foreign aid is a channel through which the Korean development experience can be passed on, studies regarding the special features of 
Korean aid, how the Korean development experience is reflected in its aid and how such development experience and official development assistance (ODA) characters will influence future international development discussions are very few. There is an aspect that the lack of studies on Korean ODA is due to the short period of Korea's involvement in the international development society as an emerging donor and having joined the OECD's Development Assistance Committee (DAC) only recently.

Korea, as a novice donor, focused a great deal of its resources on meeting the aid standards of the peer donor group mainly focusing on the improvement points of its aid so that it did not have time to look into itself. However, although discussions on development based on traditional donors' development experiences have achieved a great deal for development, at the same time they have revealed several limitations.

Thus, the world's attention is turning to the development experiences and ODA from Middle Powers and emerging donors such as Korea, BRICS and Mexico. Hence, it is time for Korea to seek for ways to contribute to the progress of international development discussions constructively by analyzing the traits, advantages and disadvantages of its own development experience and ODA whilst complying with other donors' aid standards and discussions.

This paper, as a part of such efforts, will analyze the specificities of Korean ODA with regard to how it differs from traditional donors in aid share by sector and project modality as well as what implications it will have in future international development paradigms, focusing on the following questions:

1) How does Korean ODA differ from DAC donors in sector allocation?

2) How does Korean ODA differ from DAC donors in modality?

3) How do the specificities of Korea ODA's sector allocation and project modality relate to its development experience and comparative advantages, and how do they influence future development discussions and paradigms? 


\title{
1. Overview of Korean ODA
}

\author{
History of Korean ODA
}

Korea has provided aid for developing countries since the 1960s (KOICA website 2009). It first started with inviting government officials from developing countries to participate in training programs. It has since expanded its assistance to technical assistance to developing countries including providing cash, dispatching experts and volunteers, project-type assistance and development studies such as feasibility studies, design of infrastructure, etc. With regard to concessional loans, the Economic Development Cooperation Fund (EDCF) was established in 1987 and was disbursed by the Korean Export and Import Bank (EXIM Bank) (Lee and Park 2007).

As for grant and technical assistance, various type of development assistance such as loans, grants and technical assistance were provided until 1991 by various government bodies such as the Ministry of Foreign Affairs, Finance, Health, Agriculture and others. In 1991, to increase the efficiency and coherence of the grant programs, the Korea International Cooperation Agency was established as an implementation organization to provide grants and technical assistance under the Ministry of Foreign Affairs.

The overall coordination of Korea's ODA policy and programs is undertaken by the Committee for International Development Cooperation (CIDC) chaired by the Prime Minister. Its major partners number 26 countries and 70\% of Korean ODA is distributed to these major partner countries. The ODA programs to these countries are based on Country Partner Strategies which are established for a period of three years.

\section{Outlook of Korean ODA}

Korean official development assistance first began with USD 57.4 million, and it only accounted for $0.02 \%$ of GNI. However, in 20 years time, it increased by 20 times and accounted for $0.12 \%$ of GNI in 2010 (Table 1). 
〈Table 1〉 Korean ODA (1991-2007)

\begin{tabular}{c|c|c|c|c|c|c|c|c|c|c|c|c|c|c|c|c|c|c|c|c}
\hline & '91 & '92 & '93 & '94 & '95 & '96 & '97 & '98 & '99 & '00 & '01 & '02 & '03 & '04 & '05 & '06 & '07 & '08 & '09 & '10 \\
\hline USD mil. & 57 & 76 & 111 & 140 & 116 & 159 & 185 & 182 & 317 & 212 & 264 & 278 & 365 & 403 & 752 & 455 & 699 & 802 & 816 & 1,174 \\
\hline Bilateral & 31 & 45 & 60 & 60 & 71 & 123 & 111 & 124 & 131 & 131 & 171 & 206 & 245 & 311 & 463 & 376 & 493 & 539 & 581 & 901 \\
\hline $\begin{array}{c}\text { Grants \& } \\
\text { Technical } \\
\text { Assistance }\end{array}$ & 25 & 30 & 32 & 38 & 50 & 53 & 54 & 37 & 39 & 47 & 53 & 66 & 145 & 193 & 318 & 258 & 361 & 369 & 367 & 574 \\
\hline Loan & 6 & 14 & 27 & 21 & 21 & 69 & 56 & 87 & 92 & 83 & 118 & 140 & 99 & 118 & 145 & 117 & 132 & 170 & 214 & 327 \\
\hline Multilateral & 25 & 31 & 51 & 80 & 44 & 35 & 74 & 58 & 186 & 80 & 93 & 72 & 120 & 91 & 289 & 79 & 205 & 263 & 235 & 273 \\
\hline ODA/GNI (\%) & 0.02 & 0.03 & 0.03 & 0.04 & 0.03 & 0 & 0.04 & 0.05 & 0.07 & 0.04 & 0.06 & 0.05 & 0.06 & 0.05 & 0.09 & 0.05 & 0.07 & 0.09 & 0.1 & 0.12 \\
\hline
\end{tabular}

Source: Korea International Cooperation Agency (KOICA), Korean EXIM Bank

The main motive of Korean ODA has been related to trade and investment and diplomatic purposes despite the official goal of Korean ODA being humanitarianism and assistance for the economic growth of developing countries (Lee and Park 2007). Therefore, the main recipients of Korea's ODA are Asian countries. The ODA to Asian countries had accounted for over 30\% of Korea's total ODA, and this has continuously increased to over 60\% until the 2000s (Lee and Park 2007). The sector allocation of aid has been based on its own comparative advantages and developing experiences in areas such as education, agriculture, infrastructure and telecommunication.

As the main motives of Korean ODA are derived from commercial and diplomatic reasons, loans accounted for more than 50\% of total ODA until 2003 (Table 1). However, as an effort to follow the international trend of untied and concessional aid, the share of loans has decreased, and the share of the grant and loans remain at 60:40 after 2010. ODA is also provided mostly through bilateral channels (Table 1). In 1991, its bilateral aid accounted for $79 \%$ of total aid, and as the multilateral aid increase it was reduced to around $70 \%$ nowadays.

After the 1990s, Korea concentrated its efforts on systematizing its aid architecture and becoming a DAC member by 2010. Thereby, it tried to adopt the international aid principle such as selection and concentration and specification and decreased the number of partner countries from 130-150 to 26 in 2010 (Lee and Park 2007). Moreover, Korea made greater efforts to enhance its quality of aid through strengthening planning, monitoring and evaluation. 


\section{Characteristics of Korean ODA in sector allocation}

Features of DAC donors' sector allocation since 1990

The most noticeable trend of aid sector allocation by traditional donors since 1990 is an increase in aid in the governance sector. In the late 1990s, Western donors' aid changed direction from industrial and production fields, such as agriculture or trade, to institutions, government reform, democracy, etc. This change has followed a World Bank report which argued that aid is most successful in a country where governance and institutions are well established.

Graph 1 shows that the highest share of aid was concentrated in agriculture and education during the 1990s, but in the mid-2000s, aid in these fields decreased rapidly whilst the share of aid in governance and civil society became the largest. When considering the size of the DAC's ODA by sector, aid in the latter is the largest-with its figure almost double that of other fields.

〈Graph 1〉 The share of DAC donors' aid by sector: 1991-2011

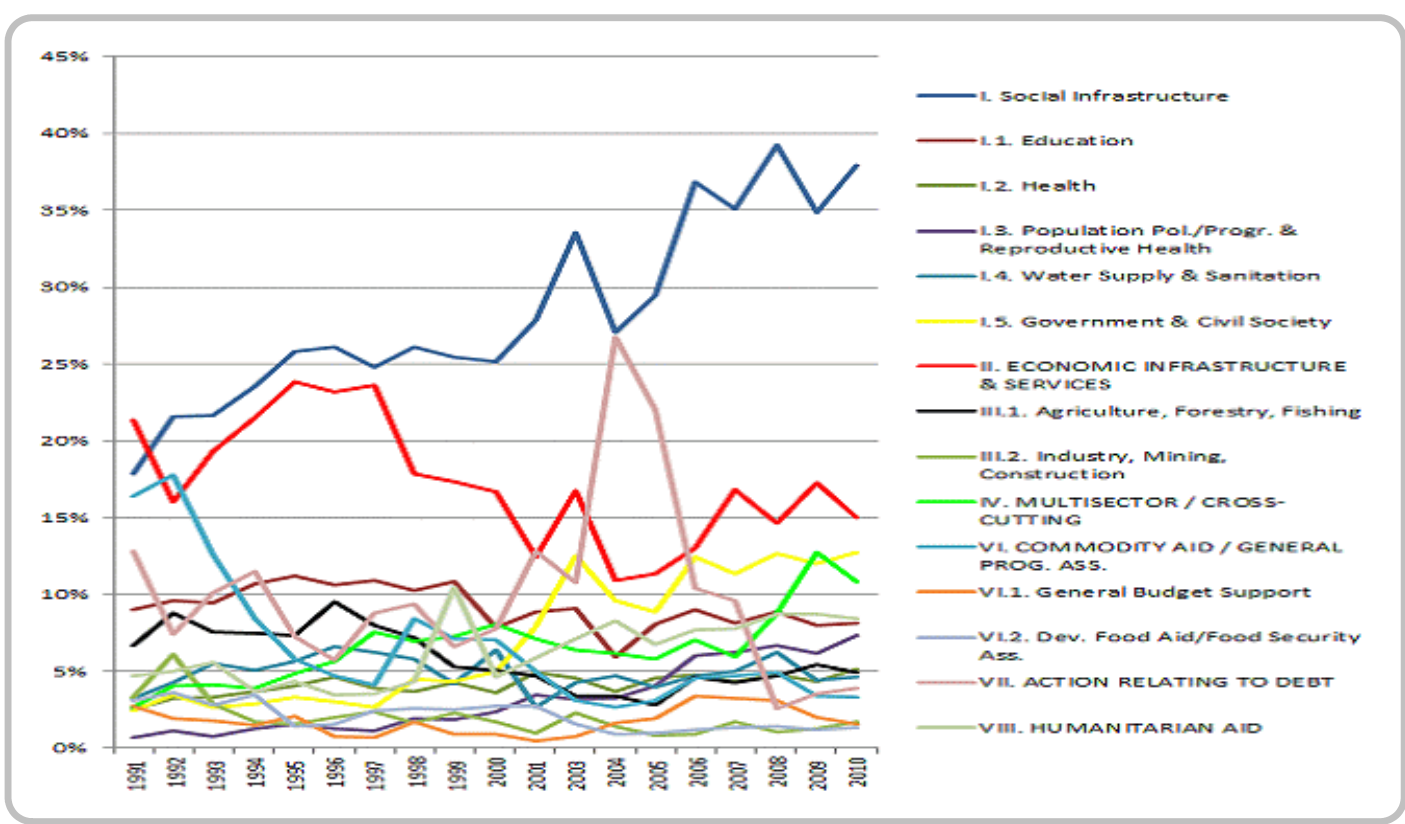

Source: www.oecd.org/dac/stats 
Moreover, the changes in the aid sector allocation pattern of DAC donors seem to be affected by the UN's Millennium Development Goals (MDGs). For example, since the MDGs were established in 2000, aid in social development areas such as education, health, governance, water supply and sanitation has shown rapid growth in contrast to aid in economic infrastructure, which has stayed at a low level since its decline in the late 1990s.

\section{Features of sector allocation of Korean ODA}

When comparing the sector allocation of Korean aid to other DAC donors, there are contrasting trends in terms of the annual share of aid in social development and economic development sectors. However, the total shares of Korean aid in the sectors of social development and economic development from 1991 to 2011 are at similar levels with $46 \%$ and $38 \%$ shares respectively. This implies that Korean aid allocation between social and economic development has been relatively balanced for the last 20 years. Although the largest shares of aid have been allocated to (in ranking order) the transport and storage, education, health and water supply and sanitation sectors for the last 20 years, excluding the transport and storage sector, comparatively equalized shares of aid have been allocated to the remaining three sectors.

It seems that the sector allocation of Korean aid also shows a radical increase in the social development sector between the early and mid-2000s, which has a deep relation to the MDGs. However, this trend changed as the share of aid in economic development soared again in the mid-2000s, and as a result, the shares of aid in both sectors remain at similar levels (Graph 3).

Korea has also increased its aid in governance and civil society, but the level is still insignificant compared to its aid towards health, education and water supply and sanitation with the former being only half that of the latter. 
〈Graph 2〉 Sector Allocation of Korean ODA (1991-2011)

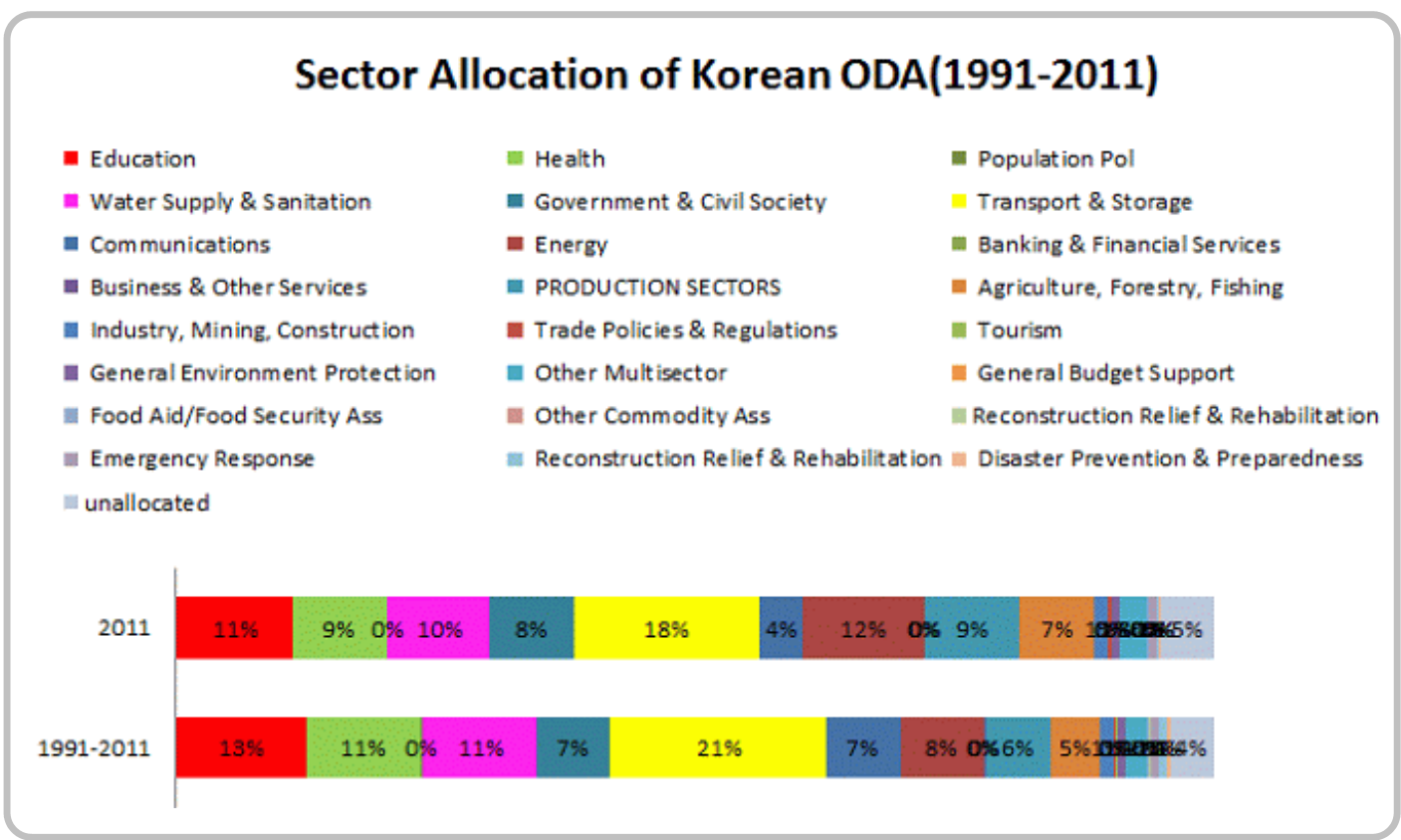

Source: OECD online database

〈Graph 3〉 Shares of Korean ODA by sector (1991-2001)

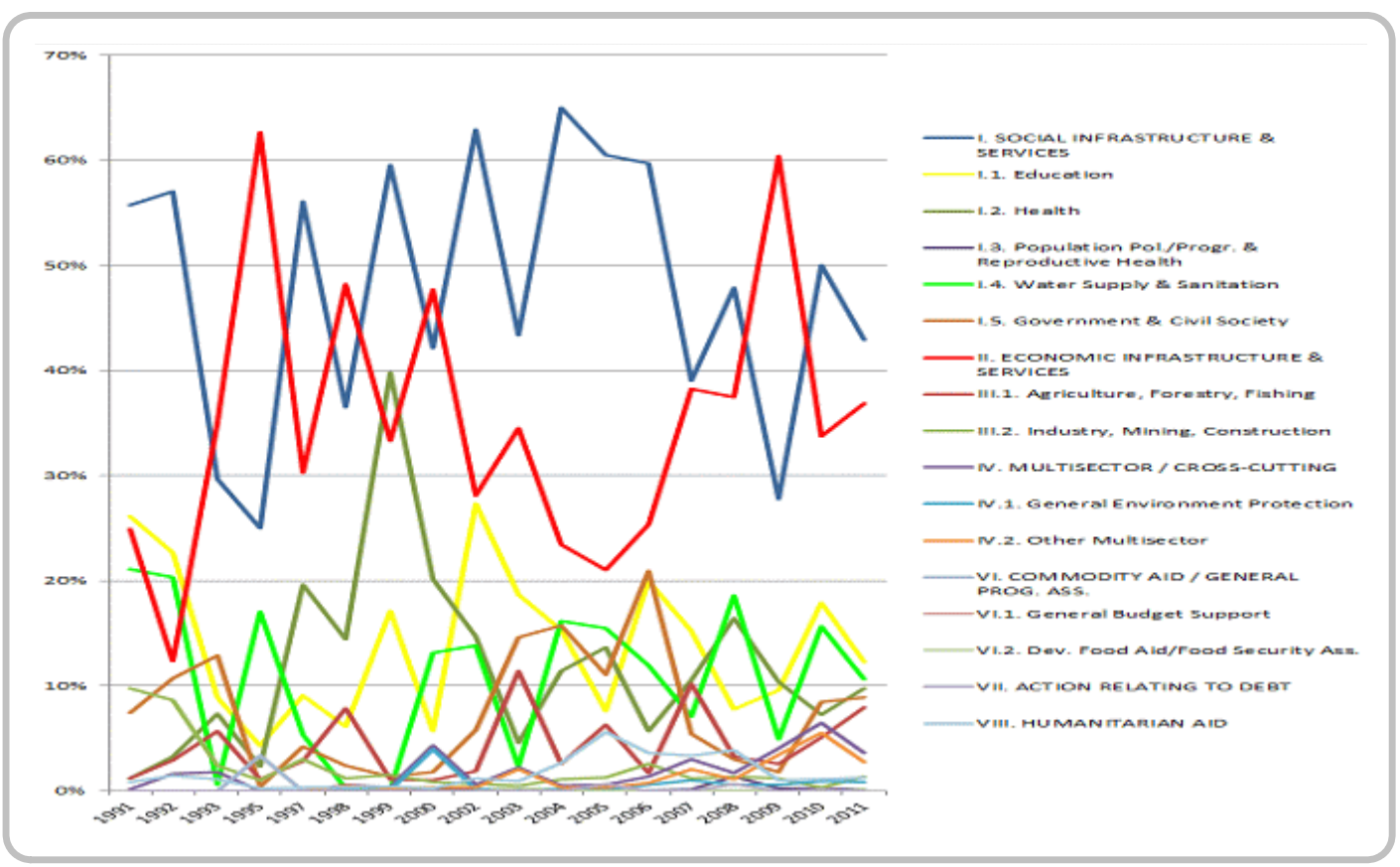

Source: OECD online database 
〈Table 2〉 Priority in sector of DAC donors and Korea

\begin{tabular}{|c|c|c|c|c|c|}
\hline DAC 1991 & \begin{tabular}{|c|} 
Volume \\
(mil. USD)
\end{tabular} & DAC 2011 & $\begin{array}{l}\text { Volume } \\
\text { (mil. USD) }\end{array}$ & Korea 2011 & $\begin{array}{c}\text { Volume } \\
\text { (mil. USD) }\end{array}$ \\
\hline $\begin{array}{c}\text { ACTION RELATING TO } \\
\text { DEBT }\end{array}$ & 7303 & $\begin{array}{c}\text { Government \& Civil } \\
\text { Society }\end{array}$ & 14404 & Transport \& Storage & 315 \\
\hline $\begin{array}{c}\text { UNALLOCATED/UNSP } \\
\text { ECIFIED }\end{array}$ & 6614 & $\begin{array}{c}\text { UNALLOCATED/UNSP } \\
\text { ECIFIED }\end{array}$ & 12395 & Energy & 206. \\
\hline Energy & 5062 & Education & 9241 & Education & 199 \\
\hline Education & 4973 & Emergency Response & 8422 & $\begin{array}{c}\text { Water Supply \& } \\
\text { Sanitation }\end{array}$ & 172. \\
\hline Transport \& Storage & 4964 & $\begin{array}{l}\text { Population Pol./Progr. } \\
\text { \& Reproductive Health }\end{array}$ & 8331 & Health & 158 \\
\hline $\begin{array}{c}\text { Water Supply \& } \\
\text { Sanitation }\end{array}$ & 1856 & Other Multisector & 7487 & $\begin{array}{c}\text { Government \& Civil } \\
\text { Society }\end{array}$ & 143 \\
\hline $\begin{array}{l}\text { Dev. Food Aid/Food } \\
\text { Security Ass. }\end{array}$ & 1781 & Energy & 6640 & Agriculture & 122 \\
\hline $\begin{array}{c}\text { General Budget } \\
\text { Support }\end{array}$ & 1556 & Transport \& Storage & 6162 & $\begin{array}{c}\text { UNALLOCATED/UNSP } \\
\text { ECIFIED }\end{array}$ & 89 \\
\hline Health & 1424 & Health & 5841 & Communications & 73 \\
\hline $\begin{array}{c}\text { Government \& Civil } \\
\text { Society }\end{array}$ & 1387 & $\begin{array}{c}\text { Water Supply \& } \\
\text { Sanitation }\end{array}$ & 5225 & Other Multisector & 45 \\
\hline $\begin{array}{l}\text { Other Social } \\
\text { Infrastructure \& } \\
\text { Services }\end{array}$ & 1231 & $\begin{array}{l}\text { General Environment } \\
\text { Protection }\end{array}$ & 4761 & Industry & 19 \\
\hline Communications & 1169 & $\begin{array}{c}\text { ACTION RELATING TO } \\
\text { DEBT }\end{array}$ & 4391 & $\begin{array}{c}\text { Other Social } \\
\text { Infrastructure \& } \\
\text { Services }\end{array}$ & 19 \\
\hline Industry & 919 & Agriculture & 4199 & Emergency Response & 15 \\
\hline $\begin{array}{c}\text { Banking \& Financial } \\
\text { Services }\end{array}$ & 677 & $\begin{array}{c}\text { Other Social } \\
\text { Infrastructure \& } \\
\text { Services }\end{array}$ & 2667 & $\begin{array}{l}\text { General Environment } \\
\text { Protection }\end{array}$ & 13 \\
\hline $\begin{array}{l}\text { Population Pol./Progr. } \\
\text { \& Reproductive Health }\end{array}$ & 398 & $\begin{array}{c}\text { Banking \& Financial } \\
\text { Services }\end{array}$ & 2240 & $\begin{array}{c}\text { Trade Policies \& } \\
\text { Regulations }\end{array}$ & 7 \\
\hline $\begin{array}{c}\text { Business \& Other } \\
\text { Services }\end{array}$ & 308 & $\begin{array}{c}\text { General Budget } \\
\text { Support }\end{array}$ & 1794 & $\begin{array}{c}\text { Disaster Prevention \& } \\
\text { Preparedness }\end{array}$ & 3 \\
\hline $\begin{array}{c}\text { Mineral Resources \& } \\
\text { Mining }\end{array}$ & 142 & Industry & 1705 & Forestry & 3 \\
\hline $\begin{array}{c}\text { Trade Policies \& } \\
\text { Regulations }\end{array}$ & 77 & $\begin{array}{c}\text { Business \& Other } \\
\text { Services }\end{array}$ & 1611 & $\begin{array}{l}\text { Population Pol./Progr. } \\
\text { \& Reproductive Health }\end{array}$ & 3 \\
\hline Construction & 23 & $\begin{array}{l}\text { Dev. Food Aid/Food } \\
\text { Security Ass. }\end{array}$ & 1479 & Fishing & 2 \\
\hline Tourism & 11 & Forestry & 1139 & $\begin{array}{c}\text { Reconstruction Relief } \\
\& \text { Rehabilitation }\end{array}$ & 2 \\
\hline $\begin{array}{c}\text { Reconstruction Relief } \\
\& \text { Rehabilitation } \\
\end{array}$ & 0 & $\begin{array}{c}\text { Trade Policies \& } \\
\text { Regulations }\end{array}$ & 790 & $\begin{array}{l}\text { Dev. Food Aid/Food } \\
\text { Security Ass. }\end{array}$ & 1.9 \\
\hline Other Multisector & 0 & $\begin{array}{l}\begin{array}{l}\text { Reconstruction Relief } \\
\text { \& Rehabilitation }\end{array} \\
\end{array}$ & 625 & Construction & 1.7 \\
\hline $\begin{array}{c}\text { General Environment } \\
\text { Protection }\end{array}$ & 0 & Other Commodity Ass. & 500 & $\begin{array}{c}\text { Banking \& Financial } \\
\text { Services }\end{array}$ & 1.4 \\
\hline Forestry & 0 & $\begin{array}{c}\text { Disaster Prevention \& } \\
\text { Preparedness }\end{array}$ & 469 & $\begin{array}{c}\text { Business \& Other } \\
\text { Services }\end{array}$ & 1.3 \\
\hline Fishing & 0 & Communications & 317 & $\begin{array}{c}\text { Mineral Resources \& } \\
\text { Mining }\end{array}$ & 0.5 \\
\hline Emergency Response & 0 & Fishing & 215 & Tourism & 0.4 \\
\hline $\begin{array}{c}\text { Disaster Prevention \& } \\
\text { Preparedness }\end{array}$ & 0 & $\begin{array}{c}\text { Mineral Resources \& } \\
\text { Mining }\end{array}$ & 175 & $\begin{array}{c}\text { ACTION } \begin{array}{c}\text { RELATING TO } \\
\text { DEBT }\end{array} \\
\end{array}$ & 0 \\
\hline Other Commodity Ass. & 0 & Tourism & 100 & Other Commodity Ass. & 0 \\
\hline Agriculture & 0 & Construction & 50 & $\begin{array}{c}\text { General Budget } \\
\text { Support }\end{array}$ & 0 \\
\hline
\end{tabular}

Source: OECD online database 
Korean ODA also differs from DAC donors in terms of its priority in sector allocation of aid (Table 2). In the case of DAC donors, their priority of aid allocation was the energy and transport sector in 1991, but in 2011, top priority was given to the governance sector. This was coupled with increased priority for social development sectors such as education and population and decreased priority for economic infrastructure sectors such as energy and transport. On the other hand, economic infrastructure sectors such as energy and transport were the top priority of Korean aid in 2011. Another distinctive aspect in the sector allocation of Korean aid is that the levels of its aid in social, economic and industry development such as energy, education, health, water supply and agriculture are at similar levels.

The features of Korean aid in sector allocation can provide a meaningful implication for the other donors as it meets the principals of the post-2015 development goals, which emphasize balanced and multidimensional development incorporating social, economic and environmental development.

Big share of aid allocated to sectors

Another difference in aid allocations between Korea and other DAC donors is that whilst Big Share of Korean aid is directly allocated to sectors, other DAC donors have consistently increased non-sector aid such as humanitarian aid including disaster relief and food aid, budget support and debt relief of which the level has risen to a similar level to that of sector aid.

\section{Concentration on "hardware" projects and comparative advantage}

In addition to the aid level according to specified sectors, Korean ODA is different from DAC donors in project modality and aid type into the details of the project.

Compared to other DAC donors, Korean aid is concentrated on "hardware" projects such as building infrastructure and facilities including construction of medical facilities, schools and vocational training centers, etc. Furthermore, when looking into the 
project details of KOICA and EDCF, the two major implementing agencies of Korean ODA, their shares of "software" projects such as services are less than $30 \%$, with the former being $23.5 \%$ and the latter $6.7 \%$ respectively (Committee for Development Cooperation, 2012).

\section{〈Table 3〉 Details of Korean and DAC donors' major aid programs by sector}

\begin{tabular}{|c|c|c|}
\hline Sector & Korea & DAC donors \\
\hline $\begin{array}{c}\text { Economic } \\
\text { Infrastructure }\end{array}$ & $\begin{array}{l}\text { Construction and improvement of } \\
\text { transportation and energy } \\
\text { infrastructure }\end{array}$ & Transportation infrastructure \\
\hline Education & $\begin{array}{l}\text { Construction or renovation of schools } \\
\text { and vocal training center, basic } \\
\text { education, training for teachers, } \\
\text { developing educational text }\end{array}$ & $\begin{array}{c}\text { Training teachers, enhancing } \\
\text { parent participation to increase } \\
\text { school enrolment, capacity } \\
\text { building, crime prevention, online } \\
\text { education }\end{array}$ \\
\hline Health & $\begin{array}{l}\text { Irrigation facilities, water tanks, } \\
\text { hospital and family planning }\end{array}$ & $\begin{array}{l}\text { Food aid, nutrition, famine, } \\
\text { HIV/AIDS, malaria, drug } \\
\text { prevention, water, social safety net }\end{array}$ \\
\hline Governance & $\begin{array}{c}\text { Computerization of administration, } \\
\text { economic and industry development } \\
\text { strategy, establishing online customs, } \\
\text { land registration systems, training for } \\
\text { government officials }\end{array}$ & $\begin{array}{l}\text { Democratization, prevention of } \\
\text { corruption, public finance, social } \\
\text { reform, decentralization, economic } \\
\text { reform, vocational training, } \\
\text { development planning, } \\
\text { micro-finance, SME, privatization }\end{array}$ \\
\hline Agriculture & $\begin{array}{l}\text { Establishment of green house, pilot } \\
\text { farms, irrigation facilities, agriculture } \\
\text { products process center, consulting } \\
\text { on market access enhancement, } \\
\text { designing agriculture sector }\end{array}$ & $\begin{array}{l}\text { Food security, small farm } \\
\text { development, commodity price } \\
\text { control, bio-fuel, improve } \\
\text { agricultural supply chain, } \\
\text { establishing international standard }\end{array}$ \\
\hline
\end{tabular}

Source: www.oed.org/dac/stats, KOICA 2013 annual plan

In Table 4, the difference between other DAC donors and Korea is revealed more clearly in the details of their projects in the governance and education sector. Although Korea has also increased its aid in the governance sector since 2000, its aid is concentrated on the government policy and administration sectors whilst other donors focus on "software" projects, such as aid towards government policy, administration, election and civil society. This is because Korea's aid work in the governance sector has been mostly focused on the computerization of government administration systems. Through 
these data, we can see that Korea puts more weight on building infrastructure even in areas which seems to have more "software" elements.

〈Table 4〉 Shares of aid allocated to education and governance, DAC donors and Korea

(unit : mil USD)

\begin{tabular}{|c|c|c|c|c|}
\hline Sector & \multicolumn{2}{|c|}{ DAC Total } & \multicolumn{2}{|c|}{ Korea } \\
\hline Education & Volume & Share & Volume & Share \\
\hline Education policy and administrative management & 1,254 & $14 \%$ & 7 & $4 \%$ \\
\hline Education facilities and training & 829 & $9 \%$ & 28 & $15 \%$ \\
\hline Teacher training & 174 & $2 \%$ & 2 & $1 \%$ \\
\hline Educational research & 20 & $0 \%$ & 0 & $0 \%$ \\
\hline Primary education & 2,152 & $23 \%$ & 9 & $5 \%$ \\
\hline Basic life skills for youth and adults & 145 & $2 \%$ & 1 & $0 \%$ \\
\hline Early childhood education & 51 & $1 \%$ & 4 & $2 \%$ \\
\hline Secondary education & 212 & $2 \%$ & 17 & $9 \%$ \\
\hline Vocational training & 482 & $5 \%$ & 45 & $25 \%$ \\
\hline Higher education & 3,706 & $40 \%$ & 46 & $25 \%$ \\
\hline Advanced technical and managerial training & 149 & $2 \%$ & 23 & $13 \%$ \\
\hline \multicolumn{5}{|l|}{ Governance } \\
\hline Public sector policy and adm. management & 2,333 & $22 \%$ & 43 & $82 \%$ \\
\hline Public finance management & 784 & $7 \%$ & 2 & $4 \%$ \\
\hline Decentralization and support to subnational govt. & 717 & $7 \%$ & 0 & $1 \%$ \\
\hline Anti-corruption organizations and institutions & 144 & $1 \%$ & 0 & $1 \%$ \\
\hline Legal and judicial development & 2,909 & $28 \%$ & 5 & $9 \%$ \\
\hline Strengthening civil society & 1,679 & $16 \%$ & 0 & $0 \%$ \\
\hline Elections & 348 & $3 \%$ & 0 & $0 \%$ \\
\hline Legislatures and political parties & 164 & $2 \%$ & 0 & $0 \%$ \\
\hline Media and free flow of information & 284 & $3 \%$ & 0 & $0 \%$ \\
\hline Human rights & 738 & $7 \%$ & 0 & $0 \%$ \\
\hline Women's equality organizations and institutions & 361 & $3 \%$ & 2 & $3 \%$ \\
\hline
\end{tabular}

Source: www. oecd.org/stats 
〈Table 5〉 Korean development experience and related ODA business

\begin{tabular}{|c|c|c|c|}
\hline & Korean development policy & Promotion of related ODA projects & $\begin{array}{l}\text { Share in } \\
\text { Korean ODA }\end{array}$ \\
\hline \multirow{4}{*}{$1950-60$} & $\begin{array}{l}\text { Dissemination of primary education } \\
\text { (compulsory education) }\end{array}$ & $\begin{array}{l}\text { Strengthening access to the primary } \\
\text { educational institutions (construction } \\
\text { of schools), establishment of compul- } \\
\text { sory primary education policy }\end{array}$ & Small \\
\hline & Land reform & $\begin{array}{l}\text { Land registration, geographic in- } \\
\text { formation systems }\end{array}$ & Small \\
\hline & Economic development strategy & $\begin{array}{l}\text { KSP, consulting on economic devel- } \\
\text { opment policy }\end{array}$ & Large \\
\hline & Dept. of Economic Planning & $\begin{array}{l}\text { Establishment of Economic Planning } \\
\text { Institute }\end{array}$ & Small \\
\hline \multirow{12}{*}{$1970-80$} & Powerful leadership & - & - \\
\hline & Export promotion policy & $\begin{array}{l}\text { Consulting programs on export pro- } \\
\text { motion policy }\end{array}$ & Large \\
\hline & $\begin{array}{l}\text { Promotion of light industry (1960) } \\
\text { and heavy and chemical industry } \\
(1970)\end{array}$ & & Very small \\
\hline & $\begin{array}{l}\text { Construction of road systems such } \\
\text { as motorways }\end{array}$ & $\begin{array}{l}\text { Construction of roads (loan) } \\
\text { feasibility studies, detailed design }\end{array}$ & Large \\
\hline & Supply of Electrical grid & $\begin{array}{l}\text { Construction of power plant, elec- } \\
\text { tricity distribution network }\end{array}$ & Large \\
\hline & $\begin{array}{l}\text { Development of water resources } \\
\text { (multi-purpose dams) }\end{array}$ & $\begin{array}{l}\text { Feasibility on construction of dam, } \\
\text { Master plan on water resource devel- } \\
\text { opment, construction of dam }\end{array}$ & Large \\
\hline & \begin{tabular}{|l|} 
Family planning service, ex- \\
pansion of medical insurance
\end{tabular} & $\begin{array}{l}\text { Family planning program } \\
\text { medical insurance program }\end{array}$ & Medium \\
\hline & Secondary education & Secondary school education & Small \\
\hline & $\begin{array}{l}\text { Expansion of the primary medical } \\
\text { institutions }\end{array}$ & Basic health care facilities & Large \\
\hline & $\begin{array}{l}\text { Fostering of human resource } \\
\text { (Vocational training center) }\end{array}$ & $\begin{array}{l}\text { Vocational training center } \\
\text { (construction of technical institutions) }\end{array}$ & Large \\
\hline & Saemaul Undong & $\begin{array}{l}\text { Saemaul Undong, farming area de- } \\
\text { velopment movement }\end{array}$ & Large \\
\hline & Efficient government structure & E-government & Large \\
\hline \multirow{7}{*}{$1980-90$} & $\begin{array}{l}\text { Initiation of environmental regu- } \\
\text { lation }\end{array}$ & Environment protection, reforestation & Medium \\
\hline & $\begin{array}{|ll|}\begin{array}{l}\text { Stabilization, reinforcement of } \\
\text { market principal, liberalization }\end{array} \\
\end{array}$ & - & Small \\
\hline & $\begin{array}{l}\text { Efforts for transition from govern- } \\
\text { ment-led to private sector-led } \\
\text { market economic system }\end{array}$ & Market-based economy & Small \\
\hline & $\begin{array}{l}\text { Strengthening of social safety net } \\
\text { (national pension, private pension, } \\
\text { disabled welfare, elderly welfare) }\end{array}$ & - & - \\
\hline & R\&D & R\&D center, R\&D promotion policy & Small \\
\hline & Building up higher education & $\begin{array}{l}\text { Building university, scholarship for } \\
\text { degree }\end{array}$ & Large \\
\hline & Democratization & Democratization, election & - \\
\hline
\end{tabular}

Source: Cooperation (Joo, D.J.et al, 2012) 
Moreover, similar to the trend of DAC donors in that they generally allocate a high level of aid in a sector where they have comparative advantages, based on the details of aid by sector (Table 7), Korea also focuses on the areas where it has past development experience and comparative advantage. For example, at a more specified level within the education sector, Korea allocated significant aid towards vocational training and education facilities as well as higher education, whereas DAC donors focus on higher education, education policy and primary education (Table 4). This seems to reflect Korea's own development experience of placing emphasis on vocational training and technical education, which aimed at fostering industrial manpower. (Table 5)

In the case of the governance sector, Korea's comparative advantage in technology for general ICT and e-government sectors, as one of the world's top five at the technology level, is also reflected in its ODA as most of its aid in this sector has been allocated to building ICT-based government administration systems such as e-government.

\section{Features of type allocation of Korean ODA}

Korean ODA programs at a specified level are largely divided into: project type aid, free-standing technical cooperation (FTC) such as the dispatch of volunteers and experts, invitation of trainees, consulting projects for policy and institution building in recipient countries, feasibility studies and designing of investment projects, cooperative projects through matching funds with private firms and CSOs, international organization cooperation projects and infrastructure building projects through loans.

During the early stages of Korean ODA, the provision of goods and materials accounted for $38.6 \%$ sharing the major type of Korean ODA. However, from the mid-1990s, project-type assistance, including the construction of buildings and infrastructure, increased to more than 30\% (Lee and Park 2007). Technical assistance also increased mainly due to the increased dispatch of volunteers, and following the 2005 tsunami and civil war in Iraq and Afghanistan, humanitarian assistance increased over 7\%, which 
had been at 2-3\% before these incidences (Lee and Park 2007). Despite this, project-type aid and provision of materials still account for more than $50 \%$ of total grants and loans.

Although Korea and DAC donors use the same definition of technical assistance, their activities are quite different. Technical assistance in Korea's aid usually refers to technical support to build infrastructure and transfer of skills to the recipients; for DAC donors' aid, it usually refers to feasibility studies and research for projects and programs, training for trainers and experts to assist international meetings and democratic elections (KOICA 2006). Looking at the statistics of aid allocation by project type, the percentages of technical cooperation and investment projects in Korean aid is much higher than those of DAC donors in their aid. Particularly, the proportion of investment projects including aid for infrastructure in Korean ODA is more than three times that of average DAC donors, which implies that Korea allocates its aid to "hardware" projects more than other donors do (Graph 4).

A high proportion of aid from DAC donors is allocated indirectly as a form of budget support, funding support, debt relief, food aid, whilst the share of the same kind of aid in Korean ODA is less than 5\%, implying that a large part of Korean ODA is carried out directly by the donor itself which includes mobilization of human resources and materials necessary for the ODA program. Furthermore, high percentage of Korean technology cooperation is due to the fact that a greater part of Korean ODA is allocated to free-standing technical cooperation (FTC), e.g., invitation of trainees and dispatch of volunteers, in comparison to the technical cooperation of other donors which. are conducted as part of projects or programs, and therefore are calculated as project-type investments.

Nonetheless, the disparity between Korea and DAC donors has decreased. For example, Graph 4 shows that the shares of Korean and DAC donors' technological cooperation were $14 \%$ and $24 \%$ respectively in 2007, but the figures were $13 \%$ and $17 \%$ in 2011 . Furthermore, in the case of investment projects, the gap in their shares between DAC donors and Korea decreased with $4 \%$ and 33\% of shares respectively in 2007 to $10 \%$ and 
46\% of shares in 2011. This can be explained that since joining the DAC, Korea has made efforts to follow the aid standards of international development society. As a result, its aid trend has become more similar to that of the international aid society, and its ODA type is becoming more multi-dimensional.

KOICA is working to start its first budget support program starting from 2013 and beginning to identify appropriate development funds to provide support. Korea's EDCF funds are also expanding its dimensions to technical cooperation programs and financial packages such as guarantee and equity investment which can be linked with its loan program. Looking at these aggressive efforts of the Korean aid agencies to expand their aid portfolios, it is expected that its aid type will look very similar to those of other donors in the near future.

\section{〈Graph 4〉 Types of Korean and DAC donors' aid}

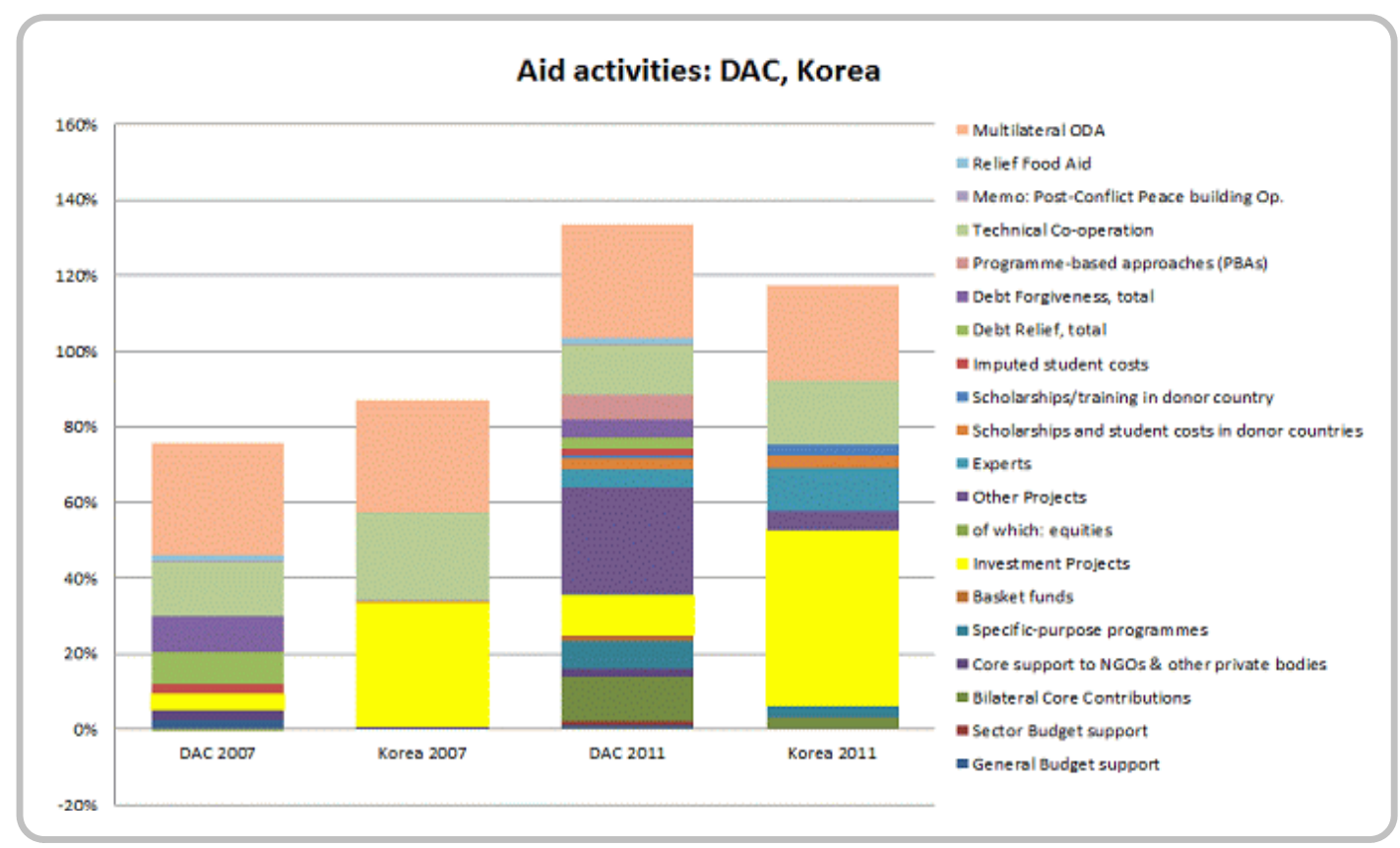

Source: www.oecd.org/dac/stats 


\section{Implication}

Features of Korean aid allocation by sector and type

This paper has analyzed the differences in the trends of Korean aid compared to DAC donors' by sector and type together with the changes in their trends.

In the previous chapter, it is found that Korean aid is allocated relatively equally between social and economic development. Another finding is that Korean aid is focused on a rather small number of sectors (less than five) such as health, education, transport, energy and agriculture, whilst other DAC donors' aid is allocated to more than ten sectors at similar levels apart from that of governance.

Moreover, Korean ODA is unique from other DAC donors in its aid allocation at a specified level within certain sectors. Compared to other DAC donors' aid focusing on the governance area within the social development sector, Korean aid is concentrated on education and health. Even within the education sector, Korean aid is focused on education facilities and vocational training, which in turn reflects the extent to which the Korean development experience and current comparative advantages are intensively utilized.

The disparity in aid allocation type is also more distinct than that of aid sector allocation. Korean aid is much more direct in nature as a large part of it is allocated to technological cooperation and investment projects carried out by dispatching human resources and materials directly to recipient countries. On the other hand, other DAC donors' aid in budget support forms, such as funding support and debt relief, is almost twice that of Korea, implying that the other DAC donors' aid is provided and implemented indirectly. Moreover, while this indirect form of aid has been increasing with time, Korean aid modality are becoming more diversified and sector allocation is becoming multidimensional-reducing the gap between Korea and other DAC donors.

Another peculiarity of Korean ODA in its sector allocation and type of allocation is that 
its share in "hardware" type projects is higher than other donors. In 2011, the share of Korean aid in economic infrastructure, which largely consists of "hardware" projects, is more than twice that of other donors on average. In sectors other than economic infrastructure, a large part of Korean aid is allocated to "hardware" projects such as the construction of schools, hospitals and irrigation canals whereas other donors are focusing on "software" projects such as policy and institution building, capacity building and awareness enhancement project such as campaigns.

The constraints of Korean ODA allocation by sector and type is the limited number of the sectors and ODA modalities. Its major sectors are limited to education, health, water supply and transport, and its modalities are also concentrated in three to four types such as project-type investment or FTC which are mainly "hardware" projects. This is due to Korea's relatively short history as a donor and its small aid scale which hinders Korea from progressing aid diversification both in terms of sector and type.

These limited and simple types of Korean aid may deter various types of activities such as budget support, technical cooperation, knowledge share, hardware and funding from being combined systematically within a certain aid project to create a synergy effect. The same problem happens in sector allocation. One can argue that the relatively balanced allocation of Korean aid to social and economic development is a positive aspect, but Korean aid project structure has a limit in meeting a complex development demand connected with various sectors, which has been highlighted in recent development discourse such as post-2015 agenda.

\section{Constraints of DAC donors' aid sector allocation and allocation type}

As discussed above, Korea differs from other DAC donors in its aid allocation. Other DAC donors' aid sector allocation and the allocation type are results of their reflection of international development discussions in the late 1990s, such as good governance, the Post Washington Consensus (PWC), MDGs and aid effectiveness. Therefore, Korea understands that its disparity from other DAC donors is due to its government not fully applying the international standards or discussions, and as a result, Korea is making 
efforts to follow other donors and improve its aid process and project modality. However, before following international development discussions, it is necessary to ensure that such discussions and aid trends are without problems.

It is found that DAC donors have radically increased their aid in social development, particularly in governance, since 2000. Although this in part resulted from their reflecting of several international development discussions including the MDGs in 2000s, and partly results from the Western donor countries' increased competitiveness in consulting, the service industry and NGOs.

However, although DAC donors' aid in the governance area has grown rapidly, their aid in economic and production sector including agriculture, forestry and fisheries, transport, communication, social infrastructure, industry sector and technological cooperation, which is directly related to growth and production, has decreased. In addition, aid in "hardware" projects such as infrastructure has rapidly decreased whereas aid in "software" projects in areas such as legal, institution and consultation have rapidly increased.

While there are not many studies on aid effectiveness by sector, increasing focus on institution and governance is also debatable since its effect on economic growth or poverty reduction is controversial in terms of whether it is a critical factor for development (Hansen and Tarp 2000), which institution is good for growth (Khan 2006) and how to create good institutions (Rodrick et al. 2004). Moreover, there are other arguments that reforms are not likely to be implemented or sustainable, due to the lack of capacity and willingness of recipient governments (Mosley and Weeks 1993, Santiso 2001). Some even argue that empirically economic development usually brings "good institutions" rather than the other way round (Chang 2003, Khan 2006); others argue that there are no one-size-fits-all institutions that can work in every country due to different social structures and contexts (Rodrick, 2004). Moreover, as issues such as the formation of democracy and exposure to corruption are connected to social and political structures, they are not technical problems that can be solved simply by building institutions (Ferguson, 1994). Therefore, aid that is excessively focused on 
governance, for which the effect on development has not been precisely determined, can rather reduce the effectiveness and efficiency of aid.

In addition to other DAC donors' aid sector allocation, their excessive concentration on "software" projects is another issue to be addressed. The reduction of aid for "hardware," especially in physical capital formation, is problematic since aid to infrastructure is generally considered to be less fungible (Lancaster 1999) and has a strong and positive effect on economic development even in the short term (Clemens et al. 2004). Even the donors assess that investment in infrastructure and facilities in the education sector directly contribute to education achievement (DFID 2004, 2). They argue although "software" factors such as teaching methods are important, these areas can be addressed after a satisfactory level of "hardware" has been achieved.

Furthermore, considering that recent post-2015 discussions on sustainable development and development effectiveness from the Pusan Global Partnership emphasize economic development and growth, donors' recent reduction in aid for economic infrastructure can be problematic. The trend of low aid levels in agriculture and industry, which have a direct connection to economic growth and poverty reduction, also need to be reconsidered. African countries pointed out that the decrease of aid towards infrastructure, agriculture, water and sanitation is problematic and recommended these sectors be readdressed since they are directly related to economic development (Commission for Africa, 2005).

Above all, prior to discussing which type and sector of aid is more effective, the issue regarding traditional donors' excessive concentration of their recent aid in certain sectors and types needs to be considered first.

Except for new DAC member countries, current Western donors' aid sector allocations and allocation types show similar patterns. As this has partly resulted from their reflection of international development discussions as mentioned above, this similarity is becoming more intensified as international development discussion expands. 
Nonetheless, the aid scale has stagnated due to the recent global economic recession, and responding to aid stagnation, the international society is emphasizing the enhancement of aid effectiveness and efficiency through the selection and concentration of aid as well as division of labor among donors. Also, post-2015 discussions put emphasis on linking various types of aid including knowledge, technology, finance and the integration of various sectors.

Taking these development discussions into account, individual donors need to select and concentrate their efforts based on their own comparative advantages. At the same time, global collective efforts are necessary to evenly distribute the selection and concentration of individual donors to various sectors so that the current issues of excessively similar donor aid patterns and unequal aid concentration to a certain sector or type are avoided.

\section{Conclusion}

DAC donors' focusing their aid on the "governance" sector and "software" programs reveals issues of unequal allocation among sectors. Furthermore, they lack in aid dedicated to economic development and sectors directly related to development as well as aid which can be incorporated into recipient countries' development strategies.

In contrast, Korean aid in economic development has been at a continuously high level and aid towards "hardware" projects has also remained at a steady level. Therefore, its share of Country Programmable Aid (CPA) is very large compared to other donors, and so there bigger possibilities for recipient countries to connect aid to their own development strategies.

Of course, this trend of Korean aid also reveals problems such as its focus on "hardware" projects which do not take sustainability into account, its simple and limited project modality and lack of ownership from recipient countries due to direct 
inputs of Korean human resources and materials. Thus, the Korean government is working on improving these drawbacks. While the drawbacks of Korean aid need to be improved and complemented, its own specific characteristics, which differ from DAC donors, can potentially complement several problems of traditional donors' aid.

Korea's consistent investment in industry and economic development sectors can be supplementary to aid from other donors that focus on institution building. Moreover, Korea can supplement what developed countries are missing through its consistent aid in "hardware" projects which are effective in the short term and have noticeable outcomes.

Also, Korea's differentiation from other donors is worth considering in the perspective of division of labor amongst donors. As the trend of Korean aid differs greatly from the average trends of other donors, adhering to its differentiated trend of aid sector allocation and allocation type may allow Korea to complement in areas where aid from other donors are lacking.

Although Korea is volunteering for a bridging role between developed and developing countries, its development experience has not been reflected strategically in its ODA policies and implementation, which is key for passing on its development experience. Even if its development experience has been reflected in its ODA, this has not been effectively melted into Korea's ODA policies or international development discussions. As a result, Korea's aid allocation types and sectors are also becoming similar to other donors. Moreover, its successful development experiences in areas such as industrialization strategy, compulsory primary education and medical insurance system does not seem to be successfully embodied into its ODA projects (Table 7).

Every donor's aid reflects its own development experience and comparative advantage (Joo, D.J., 2012). As Korea has a distinctive development experience adopted from Western donors, its ODA also differs from the latter in its shape and characteristics. Therefore, Korea needs to apply effectively its differentiated development and aid experience from other donors to its ODA policies and play a complementary role for 
what the traditional development discourse lacks. If Korea fails to embody its unique

development experience into a new development discourse and paradigm, its pledge to

play a role as a bridge between developed and developing countries may end up as an abstract slogan. 


\section{References}

Burnside, Craig, and David Dollar. "Aid policies and growth." American Economic Review 90:4(September) (American Economic Review), 2000: 847-868.

Clemens, Michael, Steven Radelet, and Rikhil Bhavnani. Counting chickens when they hatch: The short term effect of aid on growth. Working paper number 44, Center for global development, 2004.

Commission For Africa. Our Common Interest. Commission for Africa, 2005.

DFID. 2008 Autumn Performance Report. performance report, Department of International Development, 2008.

DFID. Books, Buildings and Learning outcomes: an impact evaluation of WB support to basic education in Ghana., Department of International Development, 2004.

EC. Reforming Technical Cooperation and Project Implementation Units for External Aid provided by European Commission. Backbone strategy, European Commission, 2008.

Ferguson, James. The Anti-Politics Machine: 'Development', Depoliticisation and Bureaucratic Power in Lesotho. Minneapolis: University of Minnesota Press, 1994.

Hansen, Henrick, and Finn Tarp. Aid and Growth Regression. Centre for Research in Economic Development and International Trade, 2000.

Joo. D. J. et al, Establishing Korean ODA Model, Cooperative research paper, National Research Council for Economic Humanities and Social Science, 2012

Khan, Mushtaq. Governance, Economic Growth and Development since the 1960s., Background paper for World Economic and Social Survey , 2006.

KOICA. Trends in Korea ODA and six developed countries . research paper, Korea International Cooepration Agency, 2006.

Kragelund, Peter. "The Return of non-DAC donors to Africa: New Prospects for African Development?” Development Policy Review, 2008: 555-584.

Lancaster, C. "Aid effectiveness in Africa: The unfinished agenda." Journal of African economies, , 1999: volume 8, number 4 pp487-503. 
ODI. Will "Emerging Donors" Change the Face of International Cooperation? Lecture note, Overseas Development Institute, 2006(b).

Rodrick, D, A Subramanian, and F Trebbi. "Institutions rule: the primacy of institutions over integration and geography in economic development." Journal of Economic Growth 9 (2), 2004: 131-65.

Santiso, C. "Good Governance and Aid Effectiveness:The World Bank and Conditionality." The Georgetown Public Policy Review, Volume 7 Number 1 Fall , 2001: 1-22.

World Bank. Assessing aid. New York: Oxford University Press, 1998. 